\title{
QUALITY OF IMPRESSIONS USING TWO DIFFERENT BRANDS OF POLYVINYL SILOXANE IMPRESSION MATERIALS
}

\author{
Eksi Ozsoy Hilal, ${ }^{1}$ Najafova Lamia, ${ }^{2}$ Kurtulmus Huseyin ${ }^{2}$ \\ ${ }^{1}$ Department of Prosthodontics, University of Beykent School of Dentistry, Istanbul, Turkey \\ ${ }^{2}$ Department of Prosthodontics, University of Istanbul Aydin School of Dentistry, Istanbul, Turkey
}

Primljen/Received 12. 04. 2020. god.

Prihvaćen/Accepted 26. 05. 2020. god.

Abstract: Background: This study was to evaluate the impression quality and clinical success of 2 Polyvinyl siloxane (PVS) impression materials by using dual-viscosity 1-step impression technique and the putty-wash two-step impression technique.

Methods: In this study, Variotime (Heraeus, Hanau, Germany) and a novel silicone Spirias (Imicryl, Konya, Turkey) were selected as PVS impression materials. A total of 40 samples were divided into groups according to the impression technique. Three possible categories were established to rate the impression quality. The impression was examined using a laboratory microscope (Opmi Pico, Zeiss) and lenses with 2X to 6X magnification for the presence or absence of bubbles or voids and the complete reproduction of the preparation finish line. A spreadsheet (Excel v2016; Microsoft Corp) was used for processing statistical data. Results of the analysis were calculated as mean and frequency.

Results: In the impressions taken with Variotime, the percentage of the successful impression is $95 \%$ (Criteria I - II). Only one impression was found unacceptable (criteria III). In impressions with Spirias, the percentage of successful impressions is $100 \%$ (Criteria I - II). No-impression was found unacceptable (criterion III).

Conclusion: The quality of impressions of both brands Polyvinyl siloxane impression materials revealed a high rate $(97.5 \%)$ For more precise results, many new studies were needed on different Polyvinyl siloxane impression materials.

Keywords: polyvinyl siloxane, additional silicone, quality of impression.

\section{INTRODUCTION}

Impressions made to replicate the condition of teeth and surrounding tissues are a main part of prosthetic dentistry. The purpose of acceptable impressions is to provide exact information for indirect restorations
(1). Although a successful dental prosthesis depends on many factors associated with the dentist, material, and patient, the impression is the most critical step (2).

Making the impression is a critical clinical step to accurately record the three-dimensional intraoral relationships among teeth and surrounding structures (1). Laboratory errors that lead to incompatibility in indirect restorations are most often the result of inaccuracies that occur during the impressions $(1,2,3)$. Many factors, such as the experience and skill of clinicians, proper material handling, the choice of impression materials, technique, working time, and the patient's compliance, affect the acceptability of the impression (3).

Polyvinyl siloxane impression material (PVS), also called addition silicone impression material, which has been used for many years, is one of the most commonly used impression materials for indirect denture restorations today. This material has many advantages, such as low polymerization shrinkage, virtually ideal dimensional stability and durability, good detail reproduction, non-toxic or non-allergic behavior, adequate tear resistance, and quick elastic recovery.

Its stability makes it possible to pour the molds up to several days after they have been removed from the mouth. PVS is the best choice among elastic impression materials if there is likely to be a delay in pouring the molds. Innovations in PVS impression materials aim to enhance precision and limit some clinical handicaps, such as bubbles, voids, tears, and pulls (4). On the other hand, PVS is inherently hydrophobic; because of its hydrophobic behavior, PVS applications are limited to dry conditions. A new formulation of "hydrophilic" PVS has been produced that can better penetrate moist dental surfaces (5).

PVS impression materials can be used in several techniques in accordance with the manufacturer's recommendations (6), taking into account their viscositi- 
es: the dual-viscosity one-step impression technique, the single-viscosity monophase impression technique, and the putty-wash two-step impression technique (3).

The aim of this study was to evaluate the impression quality and clinical success of two PVS impression materials by using the dual-viscosity one-step impression technique and the putty-wash two-step impression technique. The null hypothesis of this study was that there would be no difference between PVS impression materials and techniques.

\section{MATERIAL AND METHODS}

A standard maxillary dentulous acrylic model (Integra, Ankara, Turkey) was selected as the master model. Tooth 26 was prepared with the preparation finish line located in the epigingival position. In this study, Variotime (Heraeus, Hanau, Germany) and a novel silicone, Spirias (Imicryl, Konya, Turkey), were selected as PVS impression materials. The viscosity of the new PVS brand Type 3 Extra Light Body Spirias (rheometer, at shear stress of $100 \mathrm{~Pa}$ ) is $10 \mathrm{PaS}$. Sharp fin test and Consistency test results are $16 \mathrm{~mm}$ and $42-45 \mathrm{~mm}$ respectively (ISO 4823 Consistency test).

A total of 40 samples were divided into groups according to the impression technique and pouring time. Grup I is "Variotime putty and light body / one-step technique" and Grup II is "Spirias putty and extra light body / two-step technique". Spirias produces an extra light body, and the company's recommendation is to perform a two-stage impression. Variotime, which we frequently use in our routine clinical practices, suggests a single-stage impression (5). We planned our work by considering the manufacturers' suggestions.

Stock trays were used for impressions of all groups. For standardization of impression loading, a square metal plate weighing $1.5 \mathrm{Kg}$ was placed on the impression trays.

Three possible categories were established to rate the impression quality (Figure 1):

a. Perfect impressions, with an absence of voids or bubbles and perfect reproduction of the preparation finish line, were rated Criteria I.

b. Minimal defects in the impression up to $2 \mathrm{~mm}$ in diameter not involving the preparation finish line that could be corrected by the technician on the casts were considered acceptable and rated Criteria II.

c. If impressions showed bigger voids or bubbles (more than $2 \mathrm{~mm}$ in diameter) or defects involving the preparation finish line, they were categorized as unacceptable and rated Criteria III.

The impression was examined using a laboratory microscope (Opmi Pico, Zeiss) and lenses with 2X to $6 \mathrm{X}$ magnification for the presence or absence of bubbles or voids and the complete reproduction of the preparation finish line.

Table 1. The distribution of impression quality for Variotime and Spirias (No. and \%)

\begin{tabular}{|l|c|c|c|c|}
\hline & criteria I* & criteria II** & criteria III** & total \\
\hline Group I & $18(\% 90)$ & $1(\% 5)$ & $1(\% 5)$ & $20(\% 100)$ \\
\hline Group II & $19(\% 95)$ & $1(\% 5)$ & $0(\% 0)$ & $20(\% 100)$ \\
\hline total & $37(\% 92.5)$ & $2(\% 5)$ & $1(\% 2.5)$ & $40(\% 100)$ \\
\hline
\end{tabular}

*Criteria I. Perfect impressions, no voids or bubbles

**Criteria II. Acceptable impressions, minimal defects in the impression (less than $2 \mathrm{~mm}$ in diameter) or not involving the preparation finish line

***Criteria III. Unacceptable impressions, big voids or bubbles (more than $2 \mathrm{~mm}$ in diameter) or defects involving the preparation finish line

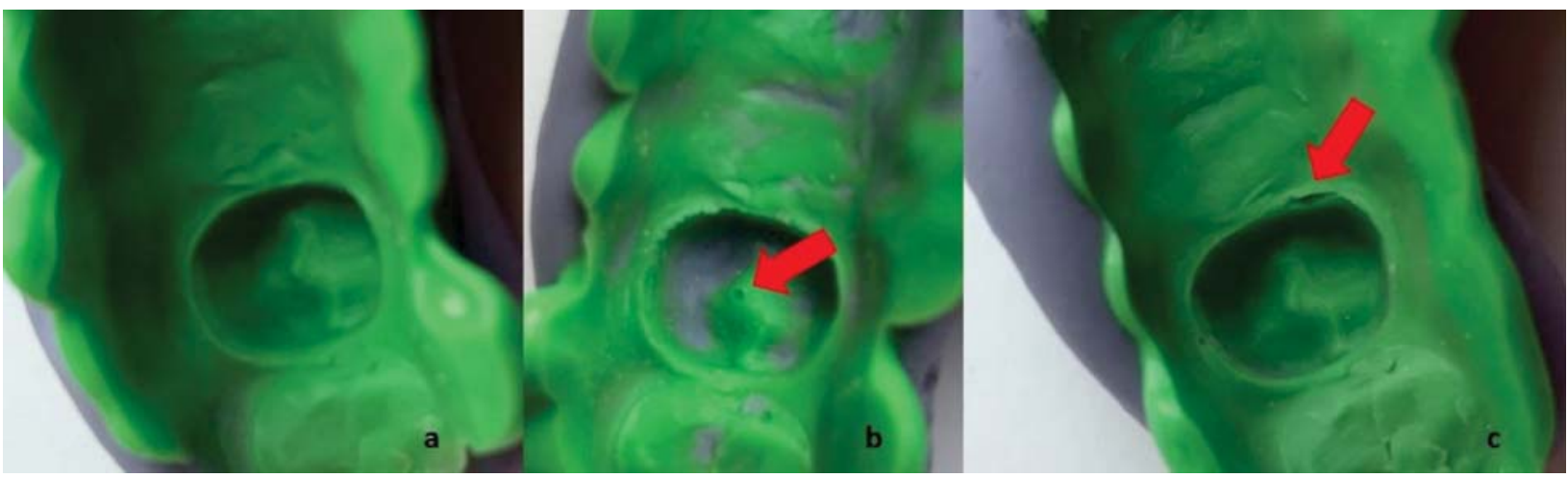

Figure 1. Three categories were established to rate the quality of the final impressions: (a) Criteria I: perfect impression, with no voids or bubbles; (b) Criteria II: acceptable impression, minimal voids or bubbles not involving the preparation finish line; (c) Criteria III: unacceptable impression, with large voids and bubbles 
A spreadsheet (Excel v2016; Microsoft Corp) was used for processing statistical data. Results of the analysis were calculated as mean and frequency.

\section{RESULTS}

Table 1 shows the number and percentages of PVS impressions according to three impression quality criteria. In the impressions taken with Variotime, the percentage of successful impressions was 95\% (criteria I-II). Only one impression was found unacceptable (criterion III). In impressions with Spirias, the percentage of successful impressions was 100\% (criteria I-II). No-impression was found unacceptable (criterion III). An acceptable percentage for all PVS impression materials is $97.5 \%$.

\section{DISCUSSION}

The aim of this in-vitro study was to evaluate the quality of impressions made with PVS materials (Variotime, Spirias), as determined by the presence or absence of bubbles or voids and the complete reproduction of the preparation finish line.

One reason for insufficient impressions is that the air bubbles between the impression material and the tooth are trapped. This may be due to the accidental shutdown of air when applying a light body material with the syringe, especially if the syringe tip is raised during the procedure. The clinician's experience and manual skill are responsible for the quality of these results. In this study, the preparations and impressions were carried out by experienced clinicians, with an overall success rate of $92.50 \%$.

The ideal impression material should have high dimensional stability, which is critical for the correct replication of intraoral structures. PVS has been used as an impression material for many years and has gained popularity due to its excellent accuracy and dimensional stability (7). Pereira et al. found that the dimensional stability of the additive silicone did not change significantly (linear size changes did not exceed 1\%), even 96 hours after measurement (8). These results are consistent with previous researchers' work (9).
In addition, the physical properties of the impression material will affect success. The PVS material used in this study offers good wettability and flow behavior in dental tissue. In general, some rules must be followed to process PVS materials. One thing to note is that rubber gloves or rubber dams are not used (10).

According to the literature, the one-step technique with PVS leads to very accurate impressions (11). The one-step technique is quite simple, cost-effective, and less time-consuming; it also protects the impression material. However, this technique has several disadvantages. First, there is no stack control. With this technique, more bubbles are produced and included in the set impression. In this study, a double stage Spirias impression showed better results than a single stage Variotime impression. However, both techniques and both brands showed close results.

\section{CONCLUSION}

Two significant conclusions were reached in this study:

1. Although the values of the Spirias sample were slightly better than the values of Variotime, the impression quality and clinical success of both PVS impression materials revealed a high rate $(97.5 \%)$

2 . For more precise results, many new studies are needed on different PVS impression materials and different techniques.

\section{Abbreviations}

PVS - polyvinyl siloxane

\section{Acknowledgment}

The authors thanks to the firm of Imicryl, Konya, Turkey.

Conflict of Interests: The authors declare that there are no conflicts of interest related to this article.

\section{Licensing}

This work is licensed under a Creative Commons Attribution 4.0 International (CC BY 4.0) License.

\title{
Sažetak
}

\section{KVALITET ZUBNOG OTISKA DVA RAZLIČCITA BRENDA POLIVINIL SILOKSAN IMPRESIONIH MATERIJALA}

\author{
Eksi Ozsoy Hilal, ${ }^{1}$ Najafova Lamia, ${ }^{2}$ Kurtulmus Huseyin ${ }^{2}$ \\ ${ }^{1}$ Department of Prosthodontics, University of Beykent School of Dentistry, Istanbul, Turkey \\ 2 Department of Prosthodontics, University of Istanbul Aydin School of Dentistry, Istanbul, Turkey
}

Uvod: Ova studija je ispitivala kvalitet zubnog otiska i klinički uspeh dva polivinil siloksan (PVS) im- presiona materijala koristeći dvostruko viskoznu monofaznu tehniku otiska i putty-wash bifaznu tehniku. 
Metode: U ovoj studiji, Variotime (Heraeus, Hanau, Nemačka) i inovativni Spirias (Imicryl, Konya, Turska) su izabrani kao PVS materijali. Ukupno 40 uzoraka je podeljeno u dve grupe prema tehnici otisaka. Određene su tri moguđe kategorije za merenje kvaliteta otiska. Utisci su ispitivani pomoću laboratorijskih mikroskopa (Opmi Pico, Zeiss) i sočivima sa uvećanjem od 2X do 6X za detektovanje prisustva mehurića ili praznina i kompletne reprodukcije završnih linija. Tabela (Excel v2016; Microsoft Corp) je koriščena za statističku obradu podataka. Rezultat analize su računati kao prosečne vrednosti i učestalosti.

\section{REFERENCES}

1. Dogan S, Schwedhelm ER, Heindl H, Mancl L, Raigrodski AJ. Clinical efficacy of polyvinyl siloxane impression materials using the one-step two-viscosity impression technique. J Prosthet Dent. 2015; 114(2): 217-22.

2. Garg S, Kumar S, Jain S, Aggarwal R, Choudhary S, Reddy NK. Comparison of dimensional accuracy of stone models fabricated by three different impression techniques using two brands of polyvinyl siloxane impression materials. J Contemp Dent Pract. 2019; 20(8): 928-34.

3. Levartovsky S, Zalis M, Pilo R, Harel N, Ganor Y, Brosh T. The effect of one-step vs. two-step impression techniques on long-term accuracy and dimensional stability when the finish line is within the gingival sulcular area. J Prosthodont. 2014; 23(2): 124-33.

4. Leao MP, Pinto CP, Sponchiado AP, Ornaghi BP. Dimensional stability of a novel polyvinyl siloxane impression technique. Brazilian J Oral Sci. 2014; 13(2): 118-23.

5. Basapogu S, Pilla A, Pathipaka S. Dimensional accuracy of hydrophilic and hydrophobic VPS impression materials using different impression techniques - an invitro study. J Clin Diagn Res. 2016; 10(2): 56-9.

\author{
Correspondence to/Autor za korespondenciju \\ Hilal Eksi Ozsoy \\ Beykent University \\ Cumhuriyet StIstanbul, TR 34550 \\ E-mail: hilaleksi@gmail.com \\ Phone: +905348792303
}

Rezultati: Kod otisaka uzetih saVariotime materijalom, procenat uspešnosti je 95\% (Kriterijumi I - II). Samo jedan otisak je bio u potpunosti neprihvatljiv (Kriterijum III). Kod otisaka uzetih Spirias materijalom, procenat uspešnosti je 100\% (Kriterijumi I - II). Nije nađen nijedan neprihvatljiv otisak (Kriterijum III).

Zaključak: Pokazana je visoka stopa uspešnosti kvaliteta otisaka oba brenda PVS impresionih materijala (97.5\%). Za preciznije rezultate, mnoge nove studije su potrebne na različitim PVS impresionim materijalima.

Ključne reč: polivinil siloksan, dodatni silikon, kvalitet zubnog otiska.

6. Kit HT. Impression Technique Guide. :33-4. Available from: http://www.brainserver.net/uploads/og/ContentImages/HealthProImages/Dental_Offers/Heraeus_Offers/36398_Variotime_StepGuide_EE.pdf

7. Ghahremanloo A, Seifi M, Ghanbarzade J, Abrisham SM, Javan RA. Effect of polyvinyl siloxane viscosity on accuracy of dental implant impressions. J Dent (Tehran). 2017; 14(1): 40-7.

8. Pereira JR, Murata KY, do Valle AL, Ghizoni JS, Shiratori FK. Linear dimensional changes in plaster die models using different elastomeric materials. Braz Oral Res. 2010; 24(3): 336-41.

9. Ahmed M, Chakmakchi M. An in vitro study to evaluate the accuracy of addition silicone and polyether impression materials after different pouring time. Al-Rafidain Dent J. 2016; 16(1): 10-8.

10. Hiremath V, Vinayakumar G, Ragher M, Rayannavar S, Bembalagi M, Ashwini BL. An evaluation of the effect of various gloves on polymerization inhibition of elastomeric impression materials: an in vitro study. J Pharm Bioallied Sci. 2017; 9(1): 132-7.

11. Franco EB, da Cunha LF, Herrera FS, Benetti AR. Accuracy of single-step versus 2-step double-mix impression technique. ISRN Dent. 2011; 2011: 341546. doi: 10.5402/2011/341546 